\title{
Effectiveness Comparation of Marketing Bali Spirit Festival: Conventional and Digital Media Promotion Towards the Visitor Interest
}

\author{
I Nengah Wirata ${ }^{1}$, Amirosa Ria Satiadji ${ }^{2}$, Luh Putu Citrawati ${ }^{3}$, Ketut Arjaya ${ }^{4}$, Ida Ayu \\ Sutarini ${ }^{5}$, IGA Ratih Asmarani ${ }^{6}$ \\ \{amirosaria@gmail.com $\left.{ }^{2}\right\}$
}

Sekolah Tinggi Pariwisata Nusa Dua Bali, Jl. Dharmawangsa, Benoa, Kec. Kuta Sel., Kabupaten Badung, Bali, Indonesia ${ }^{123456}$

\begin{abstract}
MICE and event are one of many tourism factors with a major level of development and high execution level in Indonesia, especially Bali. Bali Spirit Festival is one of international yoga festival held for 8 days in Ubud - Bali by Bali Spirit Group. Without the use of mass communication media, Bali Spirit Group would never reach a sensational number of visitors. There're a lot of views on the use of mass communication media as a promotion media, thus, it encourages the occurrence of the research on the effectiveness comparison of Bali Spirit Festival's conventional and digital media promotion towards the visitor's interest. This research would be used to measure the effectiveness of conventional and digital media usage towards Bali Spirit Festival by Bali Spirit Group visitor's interest using validities and reliability test to measure questionnaire validity as one of the data aggregation techniques, simple regression linier analysis, $t$ test, and coefficient of determination partially. Based on the analysis results, the use of conventional and digital media are effective towards visitor's interest with simple regression linier results for each variable, conventional media $\mathrm{Y}=7,770+0,391 \mathrm{X} 1$ and digital media $\mathrm{Y}=6,841+0,398 \mathrm{X} 2$. Hypothesis test results are the usage of conventional and digital media (partially) effective and have a significant effect to attract visitor's interest. Contribution amount given by conventional media towards visitor's interest is $32,7 \%$ and the other $67,3 \%$ are caused by other factors which was not researched in this study, while digital media contribution amount is $35,4 \%$ and the other $64,6 \%$ are also caused by other factors which was not researched in this study. Therefore, Bali Spirit Group shall improve the usage of mass communication media, especially digital media as Bali Spirit Festival's promotion media by using related event key words or hashtags.
\end{abstract}

Keywords: Marketing Bali; Spirit Festival; Conventional Media Promotion; Digital Media Promotion; Visitor Interest

\section{Introduction}

The Bali Spirit Festival is indeed a celebration —of the richness of culture, the sanctity of the environment, and harmony between people of all nations. This Festival has become a magnet for fans, students and followers of every yoga, movement, healing and music calling. Weeks before the Festival, Ubud begins to fill with a colourful, international tribe of conscious travellers, gathering in anticipation of one of the world's most inspiring events. The first Festival in 2008 was pulled together in just three months - an incredible achievement for 
the Festival's founders, as well as a dream come true: they shared a vision to create a Festival that would both build and support community through the full spectrum of yoga and a rich diversity of world music and dance. Media is able to give information extensively about the performance an event by various of culture products inside the event [1]. Marketing divides into two, namely traditional marketing / conventional that uses offline media such as television, radio, brochures, etc. as a tool for business marketing, as well as digital marketing or online marketing that uses the internet as a marketing medium [2]. Before entering the digitalization era, conventional mass media was the most dominating media to publish a product or event to audience. However, in this era many people think that using digital media is the most efficient tool to spread new or promote a product.

There are many perspectives regarding the effectiveness of using between conventional media or digital media. CreoHouse said that the highest level of trust is still owned by conventional media with the highest percentage of $66 \%$, whereas digital media can only reach the highest percentage of $44 \%$ [3]. On the other hand, there are also statements where the internet (digital media) has become a generator of the media industry because the internet offers so many choices and capabilities than traditional print and broadcast media. Both of these views are the main factors that encourage the research on the effectiveness comparation of the conventional and digital media to the number of visitors of The Bali Spirit Festival by PT. Bali Spirit. Based on preliminary observations, another interesting factor are the placement of The Bali Spirit Festival media promotion which is only focused in the Ubud area and the condition of the website which according to some visitors is still unclear about the location of the event. This study aims to compare the effectiveness conventional and digital media in attracting visitors to the Bali Spirit Festival. So, it is possible, after this research completed, The Bali Spirit Festival can improve the system of media promotion launch and increase the number of visitors to the Bali Spirit Festival in the following years.

\section{Methods}

This study involved 7.000 visitor of The Bali Spirit Festival 2017 they are musicians, yogis and dancers from every continent has spread across the globe. Sampling was calculated using the Slovin approach [4] and a margin of error of 5\%. From 7.000 visitor and precision level of $5 \%$, then obtained a minimum sample of 378 people as respondents.

\section{Result}

Simple Linear Regression Analysis

Conventional Media Effectiveness Coefficient on Bali Visitor Interests Spirit Festival = $7.770+0.391 X 1$. Determining the value of table using the criteria of significance level $(\alpha)$ of 0.05 , the hypothesis formulation of conventional media use in attracting visitors is: $\mathrm{H} 0: \mathrm{b} 1=$ 0 , the use of conventional media is not effective in attracting visitors. Ha: $b 1 \neq 0$, the use of conventional media is effective in attracting visitors. $\mathrm{H} 0$ is accepted if $\mathrm{t}$ count $<\mathrm{t}$ table, and $\mathrm{HO}$ is rejected if $t$ count $>t$ table.

Based on the results of the calculation it can be seen that the t-count obtained is 13,564 , while the $t$ table value is calculated using table $t$ with $\alpha$ (level of significant) $=0.05$ and degree of freedom $=n-2=378-2=376$ which is rounded to 400 because degree of freedom $=367$ 
is not attached to the table $t$ value, so that the $t$-table value is 1.966 . It can be concluded that conventional media variables have a significant relationship to the interest of visitors to the Bali Spirit Festival, so HO is rejected. The results of the t test are 13.564> 1.966 means that $\mathrm{HO}$ is rejected and $\mathrm{Ha}$ is accepted, with the conclusion that the use of conventional media is effective in attracting visitors.

Digital Media Effectiveness Coefficient on Visitor Interest in Bali Spirit Festival Y = $6.41+0.398 \mathrm{X} 2$. The results of the $t$ test according to the calculation of the digital media count (X2) are 14.402. Based on the calculation results that the t-count obtained is 14.402, while the $\mathrm{t}$-table value is calculated using table $\mathrm{t}$ with $\alpha$ (level of significant) $=0.05$ and degree of freedom $=n-2=378-2=376$ which is rounded to 400 , so that the table value is 1.966 . It can be concluded that digital media variables have a significant relationship to the interest of visitors to the Bali Spirit Festival, so H0 is rejected.

The results of the $\mathrm{t}$ test are 14.402> 1.966 means that $\mathrm{H} 0$ is rejected and $\mathrm{Ha}$ is accepted, with the conclusion that the use of digital media is effective in attracting visitors. The results of the Conventional Media Variable Determination Coefficient Analysis (X1) on the visitor interest of the Bali Spirit Festival have a positive correlation with the closeness level $\mathrm{R}=$ 0.573 or can be said to be strong. $\mathrm{R}=0.573$ means the conventional media relationship to the visitor interest of the Bali Spirit Festival in the same direction. Thus, the more the number of conventional media users, the more visitor's interest in the Bali Spirit Festival and conversely the fewer the number of conventional media users, the less visitor's interest in Bali Spirit Festival. The coefficient of determination (R-square) is 0.329 , which is the squaring of the correlation coefficient or $0.573 \mathrm{a} \times 0.573=0.329$. This shows that the contribution given by conventional media to the visitor interest of Bali Spirit Festival is $32.9 \%$, while the other $67.1 \%$ is influenced by other factors not examined in this study. This value (R-square) is considered weak because it has a bias towards the number of independent variables included in the regression model, so this study will be more inclined to use Adjusted values (R-square) which can experience ups and downs if there are additional variables. In accordance with Adjusted values (R-square), 32.7\% of visitor interest variables are caused by the use of conventional media as promotional media, while other factors are caused by other things not examined. So, conventional media has a positive and significant effectiveness in attracting visitors. Technology can be used in various fields, among others, say education, economics, social, tourism, culture, and so forth [5].

The results of the Digital Media Variable Determination Coefficient Analysis (X2) on the visitor interest of the Bali Spirit Festival have a positive correlation with the closeness level of $\mathrm{R}=0.596$ or can be said to be strong. $\mathrm{R}=0.596$ meaning is the relationship of digital media to the visitor interest of Bali Spirit Festival in the same direction. Thus, the more the number of digital media users, the more visitor's interest in Bali Spirit Festival and conversely the fewer the number of digital media users, the lesser interest in visitors to the Bali Spirit Festival will be. The coefficient of determination (R-square) is 0.356 , which is the squaring of the correlation coefficient or $0.596 \mathrm{a} \times 0.596=0.356$. This shows that the contribution given by digital media to the visitors' interest in Bali Spirit Festival is 35.6\%, while the other 64.4\% is influenced by other factors not examined in this study. In accordance with Adjusted values (R-square), $35.4 \%$ of visitor interest variables are caused by the use of digital media as promotional media, while other factors are caused by other things not examined. So, digital media has a positive and more significant effectiveness compared to the use of conventional media in attracting visitors. 


\section{Conclusion}

In accordance with the results of previous calculations, conventional and digital communication media partially can be said to be effective in attracting visitors of Bali Spirit Festival with conventional media simple linear regression equation towards visitor interest $\mathrm{Y}$ $=7.770+0.391 \mathrm{X} 1$ and digital media against visitor interest $\mathrm{Y}=6.841+0.398 \mathrm{X} 2$, which means that if the users of both media experience an increase, the same thing will happen to the interest of visitors.

a. According to the results of previous calculations, the contribution contributed by conventional media in attracting visitors to Bali Spirit Festival is $32.7 \%$, meaning that this variable has a fairly good ability to attract visitors.

b. Digital media also has a fairly good ability in attracting visitors 'interest, with a contribution of $35.6 \%$ to the visitors' interest in the Bali Spirit Festival.

c. Digital media has a higher level of effectiveness than conventional media with a difference in the percentage contribution in attracting visitor interest by $2.9 \%$.

d. Contributions given by the two mass communication media when put together will result in a contribution percentage of $68.3 \%$ to visitor interest, while the other $31.7 \%$ is caused by other factors not examined in this study, such as presale ticket launch, event content suitable and attractive, discounted prices with certain terms and conditions, ticket purchase packages and accommodations, ease of accessibility of the location of the event, etc.

\section{References}

[1] A. R. Satiadji, Sustainable Tourism Development through Events for the Culture Preservation. Paris, France: Atlantis Press, 2016.

[2] Ryan Kristo Muljono, Digital Marketing Concept. Jakarta: Gramedia, 2018.

[3] Ni Desak Made Santi Diwyarthi, Tourist Satifaction toward Homestay Management of Lumajang Regency. Denpasar: Sekolah Tinggi Pariwisata Nusa Dua Bali, 2018.

[4] Riduwan, Belajar Mudah Penelitian untuk Guru dan Karyawan dan Peneliti Pemula. Bandung: Alfabeta, 2005.

[5] I. K. Sudarsana et al., "Integrating Technology and Media in Learning Process," in Journal of Physics: Conference Series, 2019, vol. 1363, no. 1. 